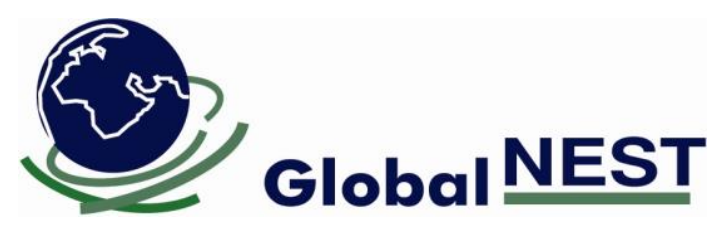

Global NEST Journal, Vol 17, No 4, pp 673-681, 2015

Copyright@ 2015 Global NEST

Printed in Greece. All rights reserved

\title{
GROUND LEVEL CONCENTRATIONS OF HYDROCARBON EMISSIONS FROM DIESEL FUELED ELECTRIC POWER GENERATORS
}

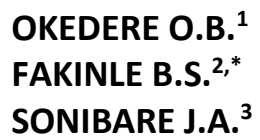

\author{
${ }^{1}$ Faculty of Engineering, Osun State University \\ Osogbo, Nigeria \\ ${ }^{2}$ Department of Chemical Engineering, LandMark University \\ Omuaran, Kwara State, Nigeria \\ Environmental Engineering Laboratory \\ ${ }^{3}$ Department of Chemical Engineering, Obafemi Awolowo University \\ Ile-Ife, Nigeria
}

Received: 15/02/2014

Accepted: 01/10/2015

*to whom all correspondence should be addressed:

Available online: $14 / 10 / 2015$

e-mail: fakinle.bamidele@Imu.edu.ng

\begin{abstract}
ISC-Aermod view dispersion model has been used to study the ground level concentration of hydrocarbon (HC). The purpose was to predict the air quality effects from off-grid diesel power generators operated by a textile factory in Lagos, Nigeria on its host airshed. Emissions from 22 point sources in 5 sections of the factory were considered with 6 different scenarios. 4 years of hourly meteorological observations were used for the investigation of dispersion. The model output showed the highest value of maximum ground level concentration at $90 \mathrm{~m}$ south east of the factory. The predicted impact using the worst case scenario showed that the ambient $\mathrm{HC}$ of the host air shed will change by $0.01-0.05 \%$ of Nigeria's Federal Ministry of Environment (FMENV) standard. HC emissions from factory will not significantly affect the host air shed as the maximum concentrations from the worst case scenario were still lower than the national standard. However, since emissions from other factories will also be released into the same host environment, an integrated approach factoring the contributions from other factories should be employed in host air quality management.
\end{abstract}

Keywords: Emission inventory, aermod view dispersion model, hydrocarbons, ground level concentration, energy, textile industry, Nigeria

\section{Introduction}

Apart from criteria air pollutants (carbon monoxide, oxides of nitrogen, oxides of sulfur and particulate matter), diesel engine exhausts are known to contain hydrocarbons. The pollutants commonly classified as hydrocarbons are composed of a wide range of organic compounds and are discharged into the atmosphere when some of the fuel remains unburned or is only partially burned during the combustion process. Most unburned hydrocarbon emissions occur when fuel droplets that are transported or injected into the quench layer during combustion. This is the region immediately adjacent to the combustion chamber surfaces, where the heat transfer outwards through the cylinder walls causes the mixture temperature to be too low to

Okedere O.B., Fakinle B.S. and Sonibare J.A. (2015), Ground level concentrations of hydrocarbon emissions from diesel fueled electric power generators, Global NEST Journal, 17(4), 673-681. 
support combustion. Partially burned hydrocarbons can occur because of poor air-fuel homogeneity due to incomplete mixing, before or during combustion; incorrect air-fuel ratios in the cylinder during combustion due to maladjustment of the air-fuel system; excessively large fuel droplets and low cylinder temperature due to excessive cooling (quenching) through the walls or early cooling of gases by expansion of the combustion volume caused by piston motion before combustion is completed (US EPA, 1979).

Several studies have reported health risks associated with exposure to hydrocarbons. Associated health hazards include eye irritation and headaches, asthma symptoms, acute childhood leukemia, acute myelogenous leukemia, and multiple myeloma (Glass et al., 2003; Kirkeleit et al., 2008; Brosselin et al., 2009; Kim et al., 2009). Health effects associated with benzene include blood disorders and immunological effects (ATSDR, 2007a, US EPA, 2011) and increase in birth prevalence of neural tube defects (Lupo et al., 2011). Health effects of xylene include eye, nose and throat irritation, difficulty in breathing, impaired lung functions and nervous system impairment (ATSDR, 2007b). Inhalation of xylene, benxene and alkanes can adversely affect the nervous system (Carpenter et al., 1978; Nilsen et al., 1988; Galvin and Marashi, 1999).

Due to transport properties, emissions are rarely retained within the point of release, they are transported through plume. To study the effects of pollutants at distances away from the source, dispersion models are commonly employed. Air dispersion modelling uses mathematical formulations to quantify the atmospheric processes that disperse a pollutant emitted by a source. Based on emissions and meteorological inputs, dispersion models can be used to predict concentrations at some selected downwind receptor locations. Such models are widely used in the management of impact of pollutant emissions on the environment (Holmes and Morawska, 2006; Kesarkar et al., 2007; Abdelrasoul et al., 2010)

In this study, emission inventory and AERMOD dispersion modelling tool were used to predict the emission rates and ground level concentrations of $\mathrm{HC}$ from generators used in a factory. This was with a view to determining the impacts of emitted $\mathrm{HC}$ on the host airshed.

\section{Materials and methods}

\subsection{Description of the study area}

The study area was a factory in Ikorodu area of Lagos State, Nigeria (Fig.1).

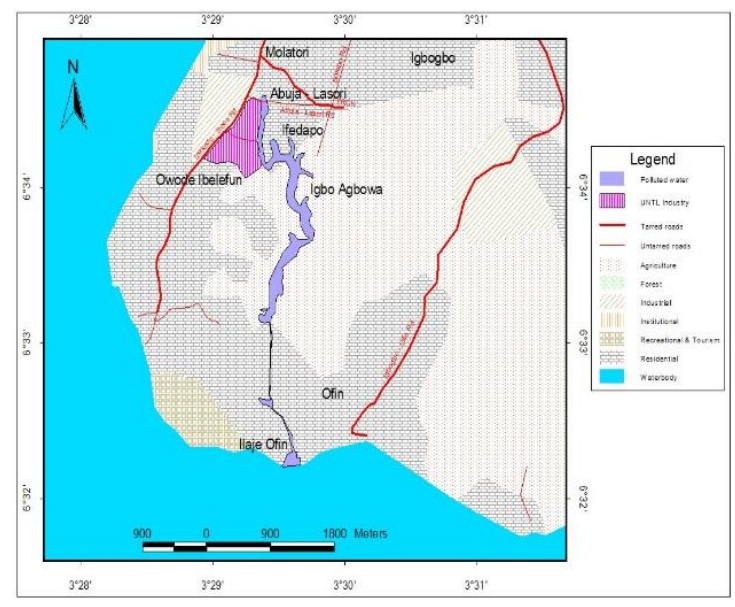

Figure 1. Study area and its host

It is located along the Lagos Lagoon, and shares boundary with Ogun State, Nigeria. Ikorodu, being a part of Lagos, is among the fastest growing urban centre in Nigeria. Rapid population and industrial growth in Ikorodu 
has affected the demand for electricity as a major source of energy. Based on 2006 Census figures (Nigeria's last official Census figures), Ikorodu had an enumerated population of 535,619 (NPC, 2006).

Diesel engine electric power generators are engaged in the factory to privately generate electricity for its activities. This is to meet up with the electric power requirements in the factory since there is presently heavy shortage of electricity from the national grid. The factory is divided into five sections and each of these is installed with dedicated diesel engine electric power generators. In all, there is a total 22 units of electric power generators with total installed capacity of 24,108 kVA.

\subsection{Emission sources in the factory}

The sources of hydrocarbon emission considered in this study are those from the 22 units electric power generators. This modelling considered hydrocarbons from each of the sections of the factory where electric power generators are installed for smooth production activities. Specifically, hydrocarbon emission sources are GRT1, GRT2, GRT3, GRT4, GRT5, GRT6, GRT7 and GRT 8 in the Spinning and weaving section; GRT9, GRT10, GRT11, GRT12 and GRT13 in the Printing and Dyeing section; GRT 14, GRT 15, GRT16 and GRT 17 in the Motel section; GRT 18, GRT 19, GRT 20 and GRT 21 in the Filament section; and GRT22 in the Fiber section.

\subsection{Emission rate determination}

The point sources (generator stacks) in the factory were identified and information on fuel usage was obtained from the factory and combined with emission factor of point sources (EPA, 1995) to calculate hydrocarbon emission as:

$$
\text { Hydrocarbon emission }(\mathrm{g} / \mathrm{s})=\mathrm{FQ} \frac{(100-\mathrm{D})}{100}
$$

Where

$\mathrm{F}=$ Fuel consumption $\left(\mathrm{I} \mathrm{s}^{-1}\right)$

$\mathrm{Q}=$ Emission factor (g/unit)

$\mathrm{D}=\%$ control efficiency

Due to lack of information on the level of efficiency of the control devices, control efficiency was assumed to be zero and Eq. (1) reduced to:

$$
\text { Hydrocarbon emission }(\mathrm{g} / \mathrm{s})=\mathrm{FQ}
$$

Hydrocarbon emission for each section was determined as the sum of emissions from point source(s) in that section while the overall emission from the factory was determined as sum of emissions from all sections in the factory.

\subsection{Dispersion modeling}

The ISC-AERMOD View air dispersion modelling tool was employed in the dispersion modelling exercise. It takes as input hydrocarbon emission rates, meteorological and land surface characteristics data. To predict the 24 hour (s) ground level concentrations of hydrocarbon emitted by point sources in the factory and their impacts on the neighbourhood, six emission scenarios based on worst cases from each section were created. Unavailability of upper air observations in the Lagos airport, the nearest synoptic meteorological station to the study location, necessitated the use of meteorological dataset from Cotonou meteorological observation. Cotonou (Benin) shares boundary with Lagos (Nigeria) and is about $106 \mathrm{~km}$ from Lagos on the west coast of Africa (Fig. 2). The meteorological station is located at Cotonou airport on coordinate $6.36^{\circ} \mathrm{N}$ and $2.38^{\circ} \mathrm{E}$ and has winds having prevalence in the southwesterly direction (Fig. 3) which is consistent with the winds observed at the project area (Sonibare and Ede, 2009; NIMET, 2011). 
The study area has predominantly overland wind source with tree heights ranging from 10-15 $\mathrm{m}$. The value used for the roughness length in this study was 0.16 for overland fetch as recommended by U.S. EPA for these types of terrain. Using land use pattern classification by Auer (1978), the study area is classified as rural. The immediate and distant environments of the factory were considered as receptors of the emitted hydrocarbons. Specifically, a $10 \mathrm{~km}$ radius within the factory location was given adequate attention. This radius is the major locations of interest and other important point of activities in the vicinity of the factory (Fig. 1).

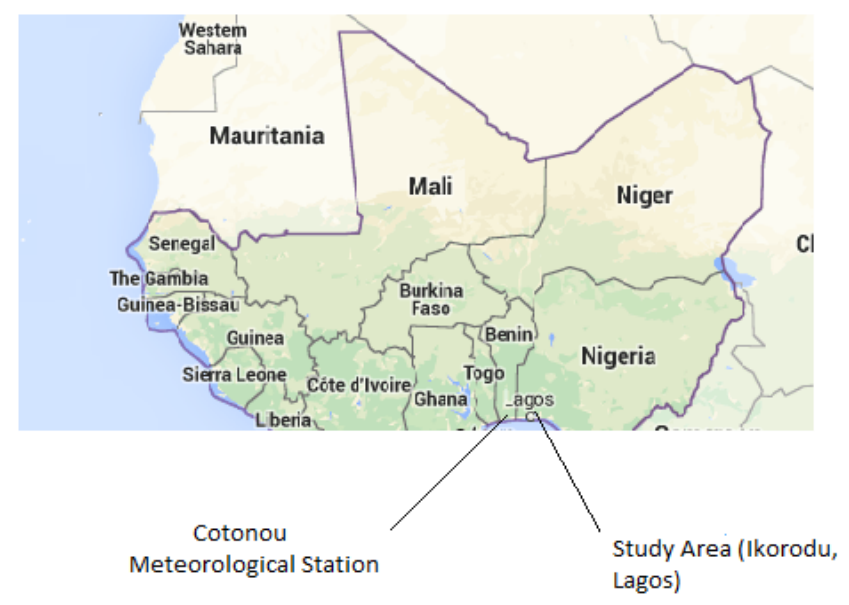

Figure 2. Map of West Africa showing the study area and meteorological station

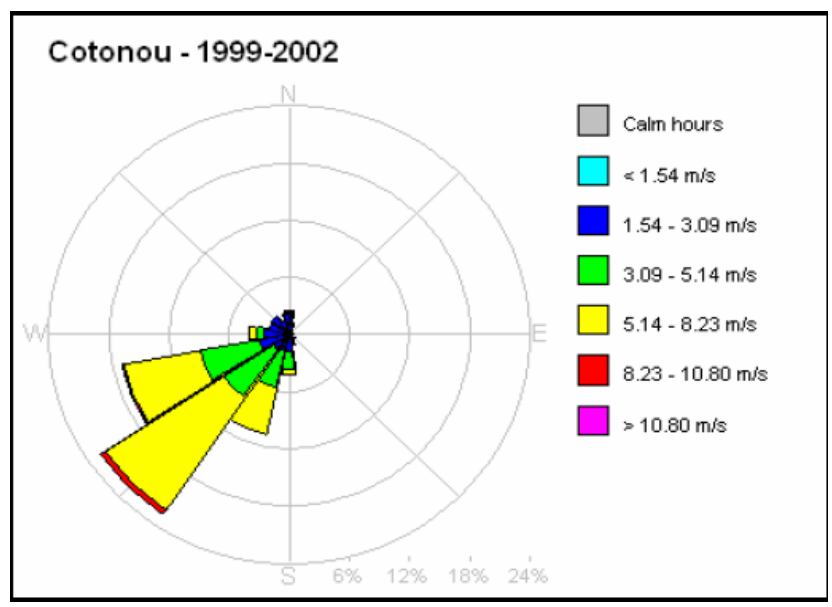

Figure 3. Windrose for Cotonou, Benin (Sonibare and Ede, 2009)

\section{Results and discussions}

The estimated hydrocarbon emission rates obtained from the diesel fuel consumption and hydrocarbon emission factor from diesel engine power generators are as summarized in Table 1.

The estimated hydrocarbon emission rates from the five sections of the factory were $0.1881,0.2734,0.0832$, 0.2592 and $0.0024 \mathrm{~g} \mathrm{~s}^{-1}$ for scenarios $1,2,3,4$ and 5 respectively while the overall hydrocarbon emission associated with the diesel power generators was $0.8063 \mathrm{~g} \mathrm{~s}^{-1}$. Due to atmospheric dispersion processes, the emitted particulate will be transported downwind. It is thus important to consider the ground level 
concentrations of the emitted particulate matter and the impact on the host air shed. The ground level concentrations of $\mathrm{HC}$ from the factory were predicted for 24-hour averaging period to be $0.03-2.61 \mathrm{\mu g} \mathrm{m}^{-3}$ (Fig. 4); $0.0-7.6 \mu \mathrm{g} \mathrm{m}^{-3}$ (Fig. 5); $0.01-4.5 \mu \mathrm{g} \mathrm{m}^{-3}$ (Fig. 6); $0.04-2.1 \mu \mathrm{g} \mathrm{m}^{-3}$ (Fig. 7) and $0.00-0.08 \mu \mathrm{g} \mathrm{m}^{-3}$ (Fig. 8) for scenarios 1-5, respectively. In scenario 6 which implied emissions from simultaneous operations of all the electric power generators in the factory, the ground level concentrations of $\mathrm{HC}$ was $0.1-7.7 \mu \mathrm{g} \mathrm{m}^{-3}$ (Fig. 9) for 24-hrs averaging period.

Table 1. Emissions Sources and Emission Rate

\begin{tabular}{|c|c|c|c|c|}
\hline \multirow[b]{2}{*}{ Factory Section } & \multirow{2}{*}{$\begin{array}{c}\text { Source/fuel } \\
\text { consumption } \\
\left.(\text { Liter s })^{-1}\right)\end{array}$} & \multicolumn{2}{|c|}{ Location (m) } & \multirow[b]{2}{*}{ Emission rate $\left(\mathrm{g} \mathrm{s}^{-1}\right)$} \\
\hline & & $x$ & $\mathbf{Y}$ & \\
\hline \multirow{8}{*}{$\begin{array}{l}\text { Spinning and } \\
\text { Weaving (Scenario 1) }\end{array}$} & GRT 1/ 0.0000 & 3149.99 & 5778.07 & 0.0000 \\
\hline & GRT 2/ 0.0043 & 3161.28 & 5789.35 & 0.0203 \\
\hline & GRT 3/ 0.0036 & 3228.99 & 5789.35 & 0.0170 \\
\hline & GRT 4/ 0.0006 & 3262.85 & 5789.35 & 0.0028 \\
\hline & GRT 5/ 0.0039 & 3307.99 & 5789.35 & 0.0184 \\
\hline & GRT 6/ 0.0039 & 3240.28 & 5766.78 & 0.0203 \\
\hline & GRT7 / 0.0082 & 3217.71 & 5766.78 & 0.0388 \\
\hline & GRT 8/ 0.0149 & 3262.85 & 5800.64 & 0.0705 \\
\hline \multirow{5}{*}{$\begin{array}{l}\text { Printing and Dyeing } \\
\text { (Scenario 2) }\end{array}$} & GRT 9/ 0.0193 & 3138.71 & 5710.35 & 0.0913 \\
\hline & GRT 10/ 0.0209 & 3104.85 & 5665.21 & 0.0988 \\
\hline & GRT 11/ 0.0049 & 3082.28 & 5653.93 & 0.0232 \\
\hline & GRT 12/ 0.0046 & 3048.43 & 5631.36 & 0.0218 \\
\hline & GRT 13/ 0.0081 & 3037.14 & 5608.79 & 0.0383 \\
\hline \multirow{4}{*}{ Motel (Scenario 3) } & GRT 14/ 0.0056 & 3228.99 & 5315.37 & 0.0265 \\
\hline & GRT 15/ 0.0048 & 3228.99 & 5270.23 & 0.0227 \\
\hline & GRT 16/ 0.0048 & 3285.42 & 5270.23 & 0.0227 \\
\hline & GRT 17/ 0.0024 & 3285.42 & 5225.09 & 0.0113 \\
\hline \multirow{4}{*}{ Filament (Scenario 4) } & GRT 18/ 0.0127 & 3082.28 & 5078.38 & 0.0601 \\
\hline & GRT 19/ 0.0229 & 3116.14 & 5078.38 & 0.1083 \\
\hline & GRT 20/ 0.0042 & 3149.99 & 5044.52 & 0.0199 \\
\hline & GRT 21/ 0.0150 & 3183.85 & 5044.52 & 0.0709 \\
\hline Fiber (Scenario 5) & GRT 22/ 0.0005 & 2867.86 & 5213.80 & 0.0024 \\
\hline
\end{tabular}

The locations of the emitted $\mathrm{HC}$ as predicted by the ISC-Aermod view dispersion modelling tool are summarized in Table 2. The maximum 24-hour averaging period ground level concentrations of HC from the Spinning and Weaving Section generators are at about $315 \mathrm{~m}$ northeast of the factory while that of the Printing and Dyeing as well as Motel sections generators are at the Factory's East Flank. From the Filament Section generators, the associated 24-hour averaging period $\mathrm{HC}$ maximum ground level concentrations are at about $180 \mathrm{~m}$ to the southeast of the factory while those emitted by the fiber section are at $187 \mathrm{~m}$ south of the factory. Whenever all the electric power generators in the factory are simultaneously operating, the predicted 24-hour averaging period maximum ground level concentrations are deposited at $90 \mathrm{~m}$ away from the factory in the southeast direction. 
Table 2. Maximum Ground Level Concentrations and their Locations

\begin{tabular}{ccc}
\hline Scenario & 24-hr concentration, $\left(\boldsymbol{\mu \mathbf { g ~ m } ^ { \mathbf { 3 } } )}\right)$ & Designation \\
\hline 1 & 2.6 & 315 m North East of Factory \\
\hline 2 & 7.6 & Factory East Flank \\
\hline 3 & 4.5 & Factory East flank \\
\hline 4 & 2.1 & 180 m South East of Factory \\
\hline 5 & 0.08 & 187 m South of Factory \\
\hline 6 & 7.7 & 90 m South East of Factory \\
\hline
\end{tabular}

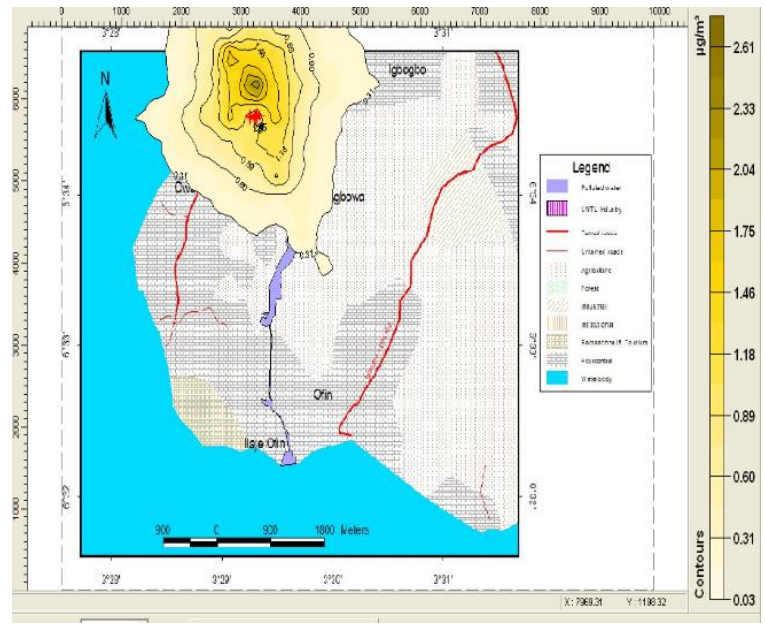

Figure 4. 24-hr ground level concentration from scenario 1

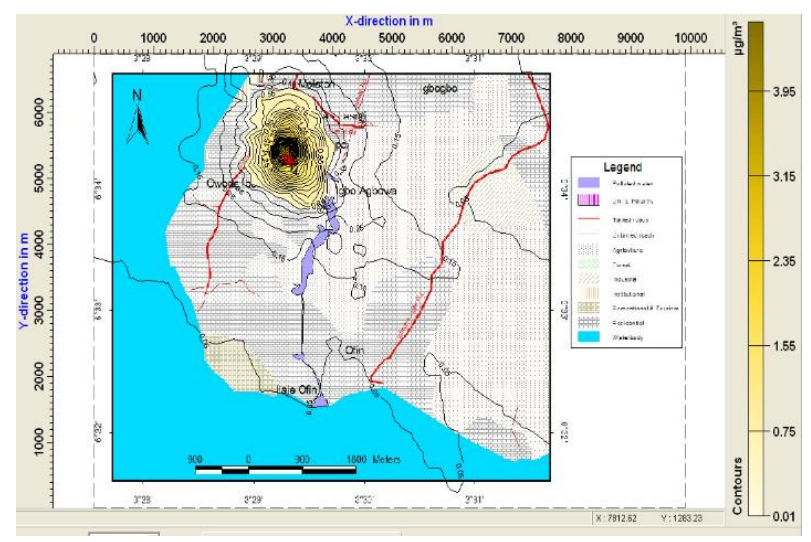

Figure 6. 24-hr ground level concentration from scenario 3

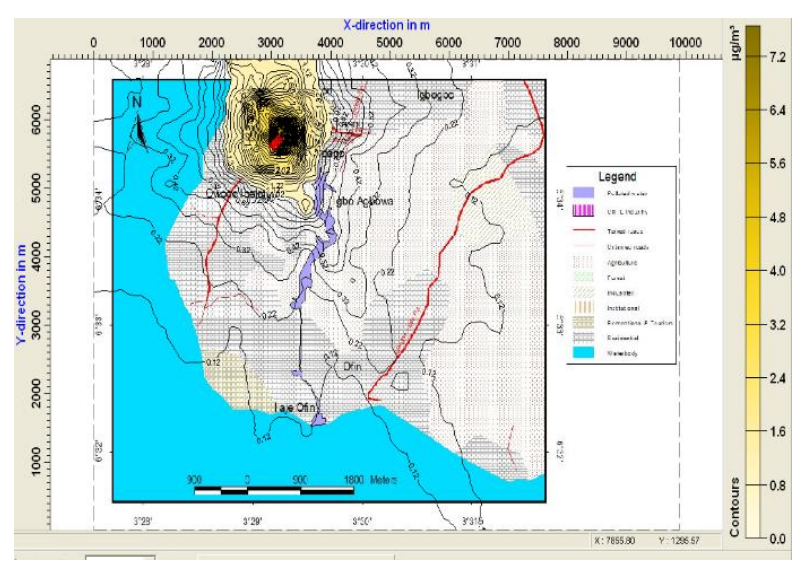

Figure 5. 24-hr ground level concentration from scenario 2

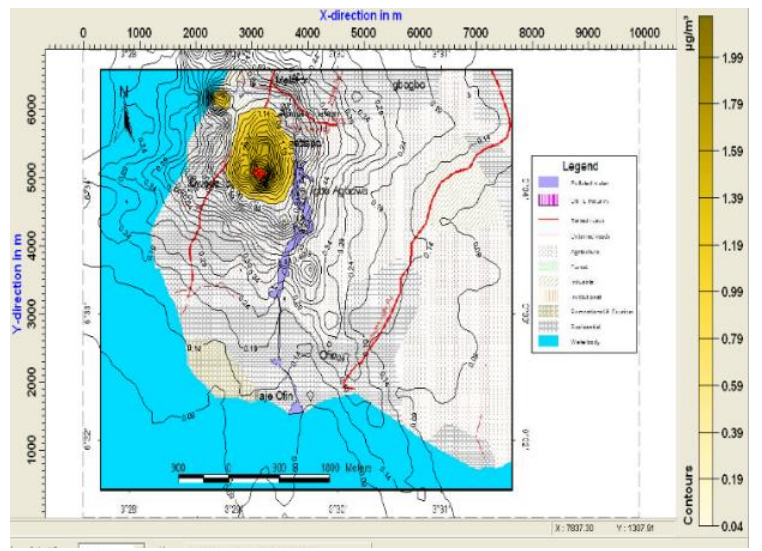

Figure 7. 24-hr ground level concentration from scenario 4 


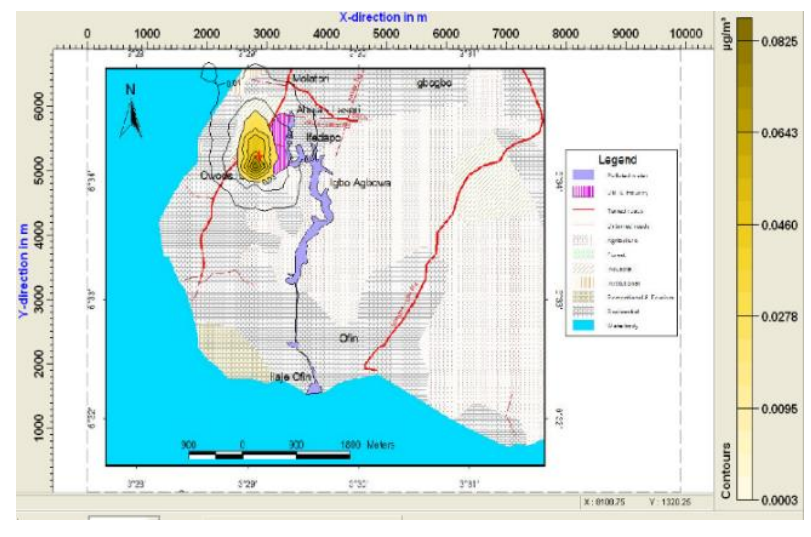

Figure 8. 24-hr ground level concentration from scenario 5

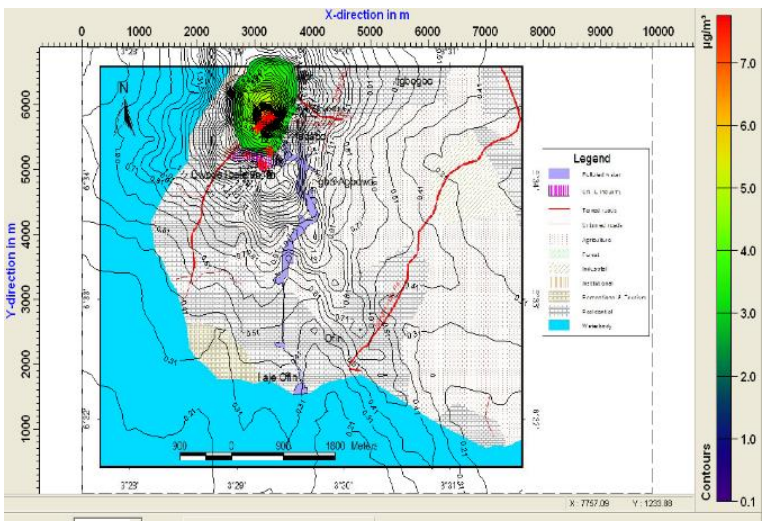

Figure 9. 24-hr ground level concentration from scenario 6

The spread of emissions is affected by climatic conditions which determine their deposition rates that influence ground level concentrations. In the plume many organic pollutants experience varying degrees of "hoping" during their environmental journey and consequently become fractionated with distance from the source (Gouin et al., 2004). There is also the possibility of both diffusion and advection away from the source, thus creating environmental problems in their surroundings (Sonibare et al., 2007).

Table 3. Impacts of emissions from different sections on host airshed

\begin{tabular}{|c|c|c|c|c|c|c|c|c|c|c|c|c|}
\hline \multirow{2}{*}{$\begin{array}{l}\text { Sensitive } \\
\text { Receptor }\end{array}$} & \multicolumn{2}{|c|}{ Scenario 1} & \multicolumn{2}{|c|}{ Scenario 2} & \multicolumn{2}{|c|}{ Scenario 3} & \multicolumn{2}{|c|}{ Scenario 4} & \multicolumn{2}{|c|}{ Scenario 5} & \multicolumn{2}{|c|}{ Scenario 6} \\
\hline & $\begin{array}{c}\text { Conc. } \\
\left(\mu \mathrm{g} \mathrm{m}^{-3}\right)\end{array}$ & $\begin{array}{l}\% \text { of } \\
\text { Limit }\end{array}$ & $\begin{array}{c}\text { Conc. } \\
\left(\mu \mathrm{g} \mathrm{m}^{-3}\right)\end{array}$ & $\begin{array}{c}\% \text { of } \\
\text { Limit } \\
\end{array}$ & $\begin{array}{c}\text { Conc. } \\
\left(\mu \mathrm{g} \mathrm{m}^{-3}\right)\end{array}$ & $\begin{array}{l}\% \text { of } \\
\text { Limit }\end{array}$ & $\begin{array}{c}\text { Conc. } \\
\left(\mu \mathrm{g} \mathrm{m}^{-3}\right)\end{array}$ & $\begin{array}{l}\% \text { of } \\
\text { Limit }\end{array}$ & $\begin{array}{c}\text { Conc. } \\
\left(\mu \mathrm{g} \mathrm{m}^{-3}\right)\end{array}$ & $\begin{array}{l}\% \text { of } \\
\text { Limit }\end{array}$ & $\begin{array}{c}\text { Conc. } \\
\left(\mu \mathrm{g} \mathrm{m}^{-3}\right)\end{array}$ & $\begin{array}{l}\% \text { of } \\
\text { Limit }\end{array}$ \\
\hline The Factory & 0.9 & 0.02 & 7.6 & 0.13 & 4.5 & 0.08 & 1.2 & 0.02 & 0.0 & 0.0 & 3.2 & 0.05 \\
\hline $\begin{array}{c}\text { Molatori } \\
\text { Receptor } 1\end{array}$ & 0.7 & 0.01 & 1.2 & 0.02 & 0.4 & 0.01 & 1.0 & 0.02 & 0.0 & 0.0 & 2.8 & 0.05 \\
\hline $\begin{array}{c}\text { Igbogbo } \\
\text { Receptor } 2\end{array}$ & 0.3 & 0.01 & 0.3 & 0.01 & 0.1 & 0.0 & 0.8 & 0.01 & 0.0 & 0.0 & 0.8 & 0.01 \\
\hline $\begin{array}{c}\text { Ifedapo } \\
\text { Receptor } 3\end{array}$ & 1.3 & 0.02 & 1.3 & 0.02 & 1.2 & 0.02 & 1.2 & 0.02 & 0.0 & 0.0 & 2.3 & 0.04 \\
\hline $\begin{array}{c}\text { Owode } \\
\text { Ibelefun } \\
\text { Receptor } 4 \\
\text { Igbo }\end{array}$ & 0.3 & 0.01 & 0.5 & 0.01 & 0.2 & 0.00 & 0.5 & 0.01 & 0.0 & 0.0 & 1.2 & 0.02 \\
\hline $\begin{array}{l}\text { Agbowa } \\
\text { Receptor } 5\end{array}$ & 0.3 & 0.01 & 0.6 & 0.01 & 0.5 & 0.01 & 0.6 & 0.01 & 0.0 & 0.0 & 1.2 & 0.02 \\
\hline $\begin{array}{l}\text { Ilaje Ofin } \\
\text { Receptor } 6\end{array}$ & 0.1 & 0.0 & 0.1 & 0.00 & 0.1 & 0.00 & 0.1 & 0.00 & 0.0 & 0.0 & 0.4 & 0.01 \\
\hline $\begin{array}{c}\text { Ofin } \\
\text { Receptor } 7\end{array}$ & 0.1 & 0.0 & 0.1 & 0.00 & 0.1 & 0.00 & 0.1 & 0.00 & 0.0 & 0.0 & 0.5 & 0.01 \\
\hline
\end{tabular}

To investigate the impacts of the hydrocarbons emitted by the factory on the host air shed, Nigeria's ambient $\mathrm{HC}$ standard for 24-hr averaging period was used as the basis for impact assessment. Summarized in Table 3 are the impacts of emissions from the factory in all the scenarios. Based on the worst case scenario (scenario 6) in which all the factory generators are in use, the $\mathrm{HC}$ of the ambient environment will change by $0.01-0.05 \%$ of the standard. The factory and receptor 1 will experience the greatest impact while receptors 6 and 7 will experience the least impact. 


\section{Conclusions}

Dispersion modeling technique has been used to investigate the impact of hydrocarbons emitted by off grid diesel engine electric power generators run by a textile factory. The predicted concentrations of hydrocarbons at all receptor locations are in compliance with Nigeria's ambient HC standard as reported in (FEPA, 1991). Based on the worst case scenario in which all the factory generators are in use, the $\mathrm{HC}$ of the ambient environment will only change by $0.01-0.05 \%$ of the Nigeria's standard. While the effects of $\mathrm{HC}$ emissions from this factory on the host airshed may not be significant on the bases of Nigeria's standard, contributions from other factories in the neighborhood could worsen the air quality conditions.

\section{References}

Abdelrasoul A.W., Al-Hadad A. and Khan A.R. (2010), Oil refineries impact on urban localities using AERMOD, American Journal of Environmental Sciences, 6(6), 505-515.

ATSDR. Toxicological Profile for Benzene. Atlanta, GA: Agency for Toxic Substances and Disease Registry, US Department of Health and Human Services; 2007a.

ATSDR. Toxicological Profile for Xylenes. Atlanta, GA: Agency for Toxic Substances and Disease Registry, US Department of Health and Human Services; 2007b.

Auer August H.Jr. (1978), Correlation of Land Use and Cover with Meteorological Anomalies, Journal of Applied Meteorology, 17, 636-643.

Brosselin P., Rudant J., Orsi L., Leverger G., Baruchel A., Bertrand Y., Nelken B., Robert A., Michel G., Margueritte G., Perel Y., Mechinaud F., Bordigoni P., Hémon D. and Clavel J. (2009), Acute Childhood Leukaemia and Residence Next to Petrol Stations and Automotive Repair Garages: the ESCALE study (SFCE), Occup Environ Med, 66(9), 598-606.

Carpenter C.P., Geary D.L., Myers R.C., Nachreiner D.J., Sullivan L.J. and King J.M. (1978), Petroleum Hydrocarbons Toxicity Studies XVII. Animal Responses to n-Nonane Vapor, Toxicol Appl Pharmacol, 44, 53-61.

Federal Environmental Protection Agency (FEPA). (1991) Guidelines to standards for environmental pollution control in Nigeria.

Galvin J.B. and Marashi F. (1999), n-Pentane, J Toxicol Environ Health, 1(58), 35-56.

Glass D.C., Gray C.N., Jolley D.J., Gibbons C., Sim M.R., Fritschi I., Adams G.G., Bisby J.A. and Manuell R. (2003), Leukemia Risk Associated with Low- Level Benzene Exposure, Epidemiology, 14(5), 569-577.

Gouin T., Mackay D., Jones K.C., Harner T. and Meijer S.N. (2004), Evidence of "Grasshopper" effect and fractionating during long range atmospheric transport of organic contaminants, Environ. Pollution, 128, 139-148

Holmes N.S. and Morawska L. (2006), A review of dispersion modeling and its application to dispersion of particles: An overview of different dispersion models available, Atmospheric environment, 40, 5902- 5928.

Kesarkar A.P., Dalvi M., Kaginalkar A. and Ojha A. (2007), Coupling of weather research and forecasting model with AERMOD for pollutant dispersion modeling. A case study of PM10 dispersion over Pune, India, Atmospheric Environment, 41, 1976-1988, DOI:10.1016/jatmosenv.2006.10.042.

Kirkeleit J., Riise T., Bratveit M. and Moen B. (2008), Increased Risk of Acute Myelogenous Leukemia and multiple Myeloma in a Historical Cohorts of Upstream Petroleum Workers Exposed to Crude Oil, Cancer Causes Control, 19(1), 13-23.

Kim B.M., Park E.K., Lee An S.Y., Ha M., Kim E.J., Kwon H., Hong Y.C., Jeong W.C., Hur J., Cheong H.K., Yi J., Kim J.H., Lee B.E., Seo J.H., Chang M.H. and Ha E.H. (2009), BTEX exposure and its health effects in pregnant women following the Hebei spirit oil spill, J Prev Med Public Health, 42(2), 96-103.

Lupo P., Symanski E., Waller D., Chan W., Langlosi P., Canfield M. and Mitchell L.E. (2011), Maternal Exposure to Ambient Levels of Benzene and Neural Tube Defects among Offspring, Texas 1999-2004, Environ Health Perspect, 119(3), 397-402. 
National Population Comission (NPC) (2006), "Population Census", Information retrived from www.npc.gov.ng in November 2012.

Nilsen O.G., Haugen O.A., Zahisen K., Halgunset J., Helseth A., Aarset A. and Eide I. (1998), Toxicity of n-C9 to n-C13 alkanes in the rat on short term inhalation, Pharmacol Toxicol, 62, 259-266.

NIMET (2011) Weather, Climate and Water Information on Nigeria. Nigeria Meteorological Agency. www.nimetng.org, Accessed on January 16, 2012.

Sonibare J.A. and Ede P.N. (2009), Potential impacts of integrated oil and gas plant on ambient air quality, Environment and Energy, 20(3), 331-344.

Sonibare J.A., Akeredolu F.A., Obanijesu E.O.O. and Adebiyi F.M. (2007), Contribution of Volatile Organic Compounds to Nigeria's Airshed by Petroleum Industry, Petroleum Science and Technology, 25, 503-516. DOI:10.1080/10916460500295397.

US EPA (1979) Standard Support and Environmental Impact Statement, Volume I: Stationary Internal Combustion Engines, EPA-450/2-78-125a, US Environmental Protection Agency, Research Triangle Park, NC.

US EPA (1995) Compilation of Air Pollutant Emission Factors Volume I: Stationary Point and Area Sources, $5^{\text {th }}$ ed. United States Environmental Protection Agency, Office of Air Quality Planning and Standards. Research Triangle Park NC 27711, USA.

US EPA (2011) Integrated Risk Information System (IRIS). Washington DC: US Environmental Protection Agency; Available: http://www.epa.gov/IRIS 